\title{
HUBUNGAN STATUS GIZI DENGAN DMF-T PADA MURID SD NEGERI 1 PITON KECAMATAN PUNUNG KABUPATEN PACITAN
}

\author{
Intan Maulia Zahra', Sri Hidayati ${ }^{2}$, Ida Chairanna Mahirawatie ${ }^{3}$ \\ ${ }^{123}$ Poltekkes Kemenkes Surabaya, Jurusan Keperawatan Gigi \\ Email : intanmauliazahra@gmail.com ; srihidayatirifan@gmail.com ; \\ chairanna@gmail.com
}

\begin{abstract}
The problem in this study is the high index of DMF-T in Piton 1 Elementary School. The purpose of this study was to find the correlation of nutritional status with DMF-T among students in Piton 1 Elementary School. This type of research is analytic observational research with cross sectional approach. The population in this study was Piton 1 Elementary School's students with a large sample of 60 students. The method used for data collection is the inspection method. The analysis technique used is the chisquare data analysis technique. The results showed that there was no relationship between nutritional status and DMF-T among students in Piton 1 Elementary School, Punung District, Pacitan Regency.
\end{abstract}

Keyword : Nutritional Status, DMF-T, Body Mass Index

Abstrak: Masalah dalam penelitian ini adalah tingginya indeks DMF-T pada murid SD Negeri 1 Piton . Tujuan penelitian ini adalah ditemukannya hubungan status gizi dengan DMF-T pada murid di SD Negeri 1 Piton. Jenis penelitian yang digunakan adalah penelitian observasional analitik dengan pendekatan cross sectional. Populasi dalam penelitian ini murid SD Negeri 1 Piton dengan jumlah besar sampel sebanyak 60 murid. Metode yang digunakan untuk pengumpulan data yaitu metode pemeriksaan. Teknik analisis yang digunakan yaitu teknik analisis data chi-square. Hasil penelitian didapatkan bahwa tidak ada hubungan antara status gizi dengan DMF-T pada murid SD Negeri 1 Piton Kecamatan Punung Kabupaten Pacitan.

Kata Kunci: Status Gizi, DMF-T, Body Mass Index

Copyright (C) 2020 Jurnal Skala Kesehatan. Politeknik Kesehatan Banjarmasin All rights reserved

Corresponding Author:

Intan Maulia Zahra

Jurusan Keperawatan Gigi Poltekkes Kemenkes

Surabaya

Email : intanmauliazahra@gmail.com 


\section{PENDAHULUAN}

Masalah gigi berlubang masih banyak dikeluhkan baik oleh anak-anak maupun dewasa dan tidak bisa dibiarkan hingga parah karena akan mempengaruhi kualitas hidup dimana mereka akan mengalami rasa sakit, ketidaknyamanan, cacat, infeksi akut dan kronis, gangguan makan dan tidur serta memiliki risiko tinggi untuk dirawat di rumah sakit, yang menyebabkan biaya pengobatan tinggi dan berkurangnya waktu belajar di sekolah [1].

Karies gigi merupakan salah satu masalah kesehatan gigi dan mulut yang sering dijumpai di masyarakat, dimana diantaranya adalah golongan anak. Mengkonsumsi makanan kariogenik berlebih dapat meningkatkan risiko karies gigi. Anak yang mengalami karies gigi dalam kurun waktu yang lama akan berpengaruh terhadap asupan zat gizi dan status gizi [2]. Target yang dicanangkan oleh WHO dan FDI saat ini adalah tidak ada lagi anak usia 12 tahun dengan DMF$\mathrm{T}>3[3]$.

Faktor yang sangat berpengaruh terhadap kesehatan gigi dan mulut salah satunya adalah pengetahuan. Pengetahuan dapat dimiliki manusia melalui panca indera yang ia miliki. Hasil penglihatan dan pendengaran dapat menjadi dasar seseorang berperilaku dalam kehidupan sehari-hari. Tingginya tingkat pengetahuan seseorang akan tercermin pada perilaku sehariharinya. Pengetahuan merupakan domain yang sangat penting untuk terbentuknya tindakan seseorang. Kurangnya pengetahuan tentang kebersihan gigi dan mulut serta dampaknya bagi kesehatan dapat mempengaruhi sikap dan tindakan seseorang [4].

Karies gigi merupakan masalah kesehatan gigi yang dapat dicegah. Pencegahan karies gigi dapat menurunkan angka kejadian karies gigi. Salah satu pencegahan karies gigi yang dapat dilakukan adalah menyikat gigi dengan pola (waktu, frekuensi, teknik) menyikat gigi yang tepat. Kebanyakan masyarakat belum mengetahui mengenai pola menyikat gigi yang tepat, terutama pada anak-anak.Pola menyikat gigi meliputi waktu, frekuensi, dan teknik menyikat gigi. Waktu menyikat gigi yang baik adalah setelah makan dan sebelum tidur. Frekuensi menyikat gigi yang optimal adalah lebih dari dua kali dalam sehari [5].

Berdasarkan hasil Riskesdas (2013) Hasil prevalensi karies aktif, pengalaman karies, penduduk $\geq 12$ tahun menurut Kabupaten/Kota Pacitan memiliki penduduk dengan karies aktif sebesar 59,6 serta riwayat karies sebesar 71,5 [6].

Hasil pemeriksaan gigi pada tanggal 7 September 2019 di SD Negeri 1 Piton, rata-rata DMFT dari 17 murid yang diperiksa sebesar 4,1 artinya setiap anak rata-rata memiliki 4 karies pada gigi tetap.

Hasil pengamatan peneliti di SD Negeri 1 Piton bahwa kondisi fisik murid SD Negeri 1 Piton sebesar $60 \%$ murid memiliki tubuh yang kecil dan tinggi badan tidak sesuai dengan badan yang dimilikinya sehingga memiliki kecenderungan kurus (wasting) .

\section{BAHAN DAN METODE}

Berdasarkan Komisi Etik Poltekkes Kemenkes Surabaya, penelitian ini dinyatakan layak etik untuk dilanjutkan. Jenis penelitian yang digunakan adalah observasional analitik dengan pendekatan cross sectional. Populasi dalam penelitian ini yakni murid SD Negeri 1 Piton. Perhitungan besar sampel menggunakan rumus slovin, hasil perhitungan sampel tersebut sebesar 60 murid.Teknik pengambilan sampel dalam penelitian ini menggunakan random sampling. Metode yang digunakan untuk pengumpulan data yaitu metode pemeriksaan dengan pemeriksaan Body Mass Index (BMI) dan pemeriksaan DMF-T. Teknik analisis dalam penelitian ini menggunakan analisis chi-square. 


\section{HASIL DAN PEMBAHASAN}

1. Karakteristik Responden Berdasarkan Jenis Kelamin Pada Murid SD Negeri 1 Piton

Jumlah siswa yang menjadi responden adalah 60 murid yang terdiri dari 26 murid laki-laki dan 34 murid perempuan. Data selengkapnya disajikan pada tabel berikut.

Tabel. 1 Distribusi Frekuensi Berdasarkan Jenis Kelamin Pada Murid SD Negeri 1 Piton Tahun

\begin{tabular}{c|c}
\multicolumn{2}{c}{2020} \\
\hline Jenis Kelamin & Frekuensi \\
\hline Laki-laki & 26 murid \\
\hline Perempuan & 34 murid \\
\hline Jumlah & $\mathbf{6 0}$ murid \\
\hline
\end{tabular}

\section{Status Gizi Pada Murid SD Negeri 1 Piton}

Berdasarkan hasil pemeriksaan status gizi pada murid di SD Negeri 1 Piton Dengan Body Mass Index (BMI) Tahun 2020 yakni dari 60 responden terdapat 27 responden dengan persentase $45 \%$ berstatus gizi gemuk serta 33 responden dengan persentase $55 \%$ berstatus gizi kurus. Data lengkap disajikan pada tabel berikut.

Tabel. 2 Distribusi Frekuensi Status Gizi Pada Murid Di SD Negeri 1 Piton Dengan Body Mass Index (BMI) Tahun 2020

\begin{tabular}{c|c|c}
\hline Status Gizi & Frekuensi & Persentase (\%) \\
\hline Gemuk & 27 & $45 \%$ \\
\hline Kurus & 33 & $55 \%$ \\
\hline Jumlah & $\mathbf{6 0}$ & $\mathbf{1 0 0} \%$ \\
\hline
\end{tabular}

Berdasarkan tabel 2 Distribusi Frekuensi Status Gizi Pada Murid Di SD Negeri 1 Piton Dengan Body Mass Index (BMI) Tahun 2020 menunjukkan bahwa lebih dari 50\% murid memiliki status gizi kurus. Hal ini menunjukkan bahwa status gizi murid di SD Negeri 1 Piton termasuk rendah. Rendahnya status gizi murid dapat dipengaruhi oleh faktor langsung, faktor tidak langsung serta faktor mendasar [7].

Berdasarkan penelitian yang dilakukan Hardiansyah (2018) tentang analisis status gizi siswi sekolah dasar di Kenagarian Air Bangis mengatakan bahwa status gizi dapat dipengaruhi oleh faktor eksternal seperti pendapatan, pendidikan, pekerjaan, dan budaya. Pendapatan dapat berpengaruh karena masalah gizi disebabkan karena kemiskinan dimana indikatornya adalah taraf ekonomi keluarga, sedangkan taraf ekonomi erat hubungannya dengan daya beli yang dimiliki oleh keluarga tersebut dalam pemenuhan gizi sehari-hari [8].

Pendidikan tentang gizi sangat diperlukan karena sebagai bentuk proses merubah pengetahuan, sikap dan perilaku orang tua untuk mewujudkan status gizi yang baik dalam keluarga [8]. Pekerjaan khususnya pekerjaan ibu juga merupakan sesuatu yang harus dilakukan untuk menunjang kehidupan keluarga pada era masa kini. Namun, bekerja umumnya merupakan kegiatan yang menyita waktu. Hal ini berpengaruh terhadap kualitas pemenuhan gizi dalam keluarga yang tidak optimal yang tergantung pada jenis pekerjaan seperti buruh pabrik, petani, serta wanita karir. Sedangkan budaya merupakan suatu ciri khas yang akan mempengaruhi tingkah laku dan kebiasaan mengatur pola makan yang baik seperti budaya sarapan pagi yang terbiasa dalam suatu keluarga.

Menurut [7] bahwa status gizi dipengaruhi oleh beberapa faktor , salah satunya seperti penyakit infeksi dan pola asuh. Dalam penelitian [9] terdapat hubungan yang bermakna antara penyakit infeksi terhadap status gizi . Riwayat penyakit infeksi pada saluran pernafasan yang disebut dengan penyakit ISPA pada anak, selain itu pernahnya terjadi 
infeksi pada pencernaan yang memicu penyakit tuberculosis. Semua penyakit yang disebabkan oleh anak itu sendiri dikarenakan faktor bakteri yang disebabkan oleh sumber makanan serta sanitasi lingkungan yang tidak hygiene [9].

Dalam penelitian [10] tentang status gizi berdasarkan indeks antropometri TB/U dan IMT/U pada anak di SD Negeri Banyuanyar II Surakarta mengatakan bahwa faktor lain yang menyebabkan anak kekurangan gizi adalah adanya infeksi dan penyakit yang ditularkan. Anak-anak biasanya mudah tertular penyakit serta sering mengalami infeksi yang umumnya dikarenakan kegiatan yang sangat aktif di tempat yang kurang bersih. Infeksi memengaruhi status gizi dengan berbagai cara seperti hilangnya zat gizi , terjadinya anoreksia disebabkan karena respon inflamasi, penurunan absorpsi makanan karena kerusakan usus, peningkatan kebutuhan zat gizi akibat dari metabolic rate yang meningkat, serta kehilangan zat gizi karena diare [10].

Kemudian dalam penelitian [9] juga terdapat hubungan yang bermakna pola asuh dengan status gizi. Peran keluarga terutama ibu dalam mengasuh anak anak menentukan tumbuh kembang anak, perilaku ibu dalam menyusui atau memberi makan, cara makan yang sehat , memberi makanan yang bergizi dan mengontrol besar porsi yang dihabiskan akan meningkatkan status gizi anak [9].

Tingkat pendapatan orang tua juga dapat mengakibatkan terjadinya kegemukan. Pendapatan yang tinggi memengaruhi pemilihan jenis dan jumlah makanan yang dikonsumsi. Pola makan praktis dan siap saji pada era masa kini yang dikonsumsi secara berlebih dan terus menerus akan menimbulkan obesitas (kegemukan) [10]. Peranan orang tua sangat diperlukan dalam mengatur pola makan pada anak agar mendapatkan gizi yang seimbang, tidak memberikan uang jajan berlebihan karena jajanan/makanan yang dikonsumsi anak-anak sekolah belum tentu sehat dan bergizi.

\section{DMF-T Pada Murid SD Negeri 1 Piton}

Berdasarkan hasil pemeriksaan DMF-T pada murid di SD Negeri 1 Piton tahun 2020 yakni dari 60 responden terdapat 54 responden dengan persentase 90\% berstatus DMF-T tinggi serta 6 responden dengan persentase $10 \%$ berstatus DMF-T rendah. Data disajikan pada tabel berikut.

Tabel. 3 Distribusi Frekuensi DMF-T Pada Murid Di SD Negeri 1 Piton Tahun 2020

\begin{tabular}{c|c|c}
\hline DMF-T & Frekuensi & Persentase (\%) \\
\hline Tinggi & 54 & $90 \%$ \\
\hline Rendah & 6 & $10 \%$ \\
\hline Jumlah & $\mathbf{6 0}$ & $\mathbf{1 0 0 \%}$ \\
\hline
\end{tabular}

Berdasarkan Tabel 3 Distribusi Frekuensi DMF-T Pada Murid Di SD Negeri 1 Piton Tahun 2020 menunjukkan bahwa sebesar 90\% murid memiliki DMF-T tinggi. Hal ini menunjukkan bahwa indeks karies pada murid termasuk tinggi. Tingginya indeks karies dapat disebabkan karena karies merupakan penyakit multifaktoral yang memiliki beberapa faktor penyebab antara lain mikroorganisme, substrat, waktu, serta gigi.

Penelitian [11] tentang hubungan konsumsi jenis makanan kariogenik dengan kejadian karies gigi pada anak di SDN Krandon Kudus mengatakan bahwa terdapat hubungan antara konsumsi jenis makanan kariogenik dengan kejadian karies. Hal ini disebabkan karena siswa memiliki kesadaran yang kurang untuk merawat kesehatan gigi dan mulutnya. Kebiasaan membeli jajanan seperti siomay, coklat, permen dan roti yang dijual di SDN Krandon Kudus memiliki pengaruh yang besar dimana siswa mengkonsumsi makanan tersebut setiap hari. Selain itu, kurangnya kebiasaan menggosok gigi mempercepat kejadian karies pada anak.

Berdasarkan penelitian [12] mengatakan bahwa lingkungan siswa memiliki pengaruh 
terhadap terjadinya karies. Hal ini disebabkan pada saat jam istirahat siswa cenderung mengonsumsi jajanan yang berada di dalam maupun di luar sekolah. Lingkungan sekolah yang memiliki banyak warung dan tempat makan serta banyaknya pedagang kaki lima yang berjualan di sekitar sekolah memiliki pengaruh terhadap terjadinya karies pada siswa.

Penelitian [13] tentang hubungan peran orang tua dengan kejadian karies gigi pada anak SDN. 005 Kepenuhan ditemukan bahwa terdapat hubungan yang signifikan antara peran orang tua terhadap kejadian karies. Orang tua tidak dapat mengontrol anak dalam mencegah terjadinya karies gigi secara penuh, karena anak-anak mempunyai aktifitas lainnya seperti pergi ke sekolah, pergi les, mengaji (MDA), bermain dan lain-lainnya.

Pemanfaatan pelayanan kesehatan gigi juga berpeluang sebagai bentuk pencegahan karies gigi. Pada penelitian [13] mengatakan bahwa dalam pemanfaatan pelayanan kesehatan gigi pada anak disebabkan karena keikutsertaan peran orang tua dalam pengawasan kesehatan gigi dan mulut anaknya. Kesadaran orang tua dalam mengawasi kesehatan gigi dan mulut anaknya tidak terlepas akan pengetahuan yang dimiliki oleh orang tua itu sendiri.

Tingginya angka DMF-T pada murid SD Negeri 1 Piton dapat dimungkinkan karena waktu dan cara menggosok gigi yang tidak tepat serta kurangnya pengawasan orang tua dalam pemeliharaan kesehatan gigi dan mulut anaknya. Pengetahuan akan waktu yang tepat dalam menggosok gigi kemungkinan murid sudah mengetahui, namun apabila cara/teknik dan frekuensi tidak terpantau merupakan pengaruh yang besar terhadap tingginya angka DMF-T. Pemantauan kesehatan gigi dan mulut dapat dilakukan oleh dokter kecil ataupun kader gigi yang memantau perilaku menggosok gigi murid lainnya.

\section{Tabulasi Silang Status Gizi Dengan DMF-T Pada Murid SD Negeri 1 Piton}

Berdasarkan hasil tabulasi silang status gizi dengan DMF-T pada murid di SD Negeri 1 Piton yang diperoleh data dari 27 respoden berstatus gizi gemuk 4 diantaranya memiliki indeks DMF-T rendah. Dari 27 responden berstatus gizi gemuk 23 diantaranya memiliki indeks DMFT tinggi. Sedangkan dari 33 responden berstatus gizi kurus 2 diantaranya memiliki indeks DMF-T rendah. Dari 33 responden berstatus gizi kurus 31 diantaranya memiliki indeks DMFT tinggi. Responden terbanyak merupakan responden berstatus gizi kurus dengan DMF-T tinggi dengan jumlah sebesar 31 responden. Data lengkap disajikan pada tabel berikut.

Tabel. 4 Hasil Tabulasi Silang Status Gizi Dengan DMF-T Pada Murid Di SD Negeri 1 Piton Tahun 2020

\begin{tabular}{ll|r|r|r}
\hline & & \multicolumn{2}{|c|}{ DMF-T } & \multirow{2}{*}{ Total } \\
\cline { 3 - 5 } & & Rendah & Tinggi & \\
\hline Status Gizi & Gemuk & 4 & 23 & 27 \\
& & & & \\
\cline { 3 - 5 } & Kurus & 2 & 31 & 33 \\
\hline Total & 6 & 54 & 60 \\
\hline
\end{tabular}

\section{Hubungan Status Gizi Dengan DMF-T Pada Murid SD Negeri 1 Piton}

Analisis data hubungan status gizi dengan DMF-T pada murid di SD Negeri 1 Piton tahun 2020 menggunakan uji Chi-Square dengan nilai signifikansi 0,05. Apabila nilai taraf signifikansi 0,05 , berdasarkan tabel tersebut diperoleh nilai signifikansi 0,261 ( nilai sig 0,261 $\geq 0,05$ ). $\mathrm{Hal}$ ini menunjukkan bahwa $\mathrm{H}_{0}$ diterima yang berarti tidak ada hubungan antara status gizi dengan DMF-T pada murid SD Negeri 1 Piton tahun 2020. Data lengkap disajikan pada tabel berikut. 
Tabel. 5 Hubungan Status Gizi Dengan DMF-T Pada Murid Di SD Negeri 1 Piton Tahun 2020

\begin{tabular}{|c|c|c|c|c|c|}
\hline & \multicolumn{2}{|c|}{ DMF-T } & \multirow[b]{2}{*}{ Total } & \multirow{2}{*}{$\begin{array}{l}\text { Asym. } \\
\text { Sig. } \\
\text { (2- } \\
\text { sided) }\end{array}$} \\
\hline & & Rendah & Tinggi & & \\
\hline \multirow{2}{*}{$\begin{array}{l}\text { Status } \\
\text { Gizi }\end{array}$} & Gemuk & 4 & 23 & 27 & \multirow{3}{*}{0,261} \\
\hline & Kurus & 2 & 31 & 33 & \\
\hline Total & & 6 & 54 & 60 & \\
\hline
\end{tabular}

Berdasarkan Tabel 5 Hubungan Status Gizi Dengan DMF-T Pada Murid Di SD Negeri 1 Piton Tahun 2020 diperoleh nilai signifikansi 0,261 (nilai sig 0,261 $\geq 0,05$ ). Hal ini menunjukan bahwa $\mathrm{H}_{0}$ diterima yang berarti tidak ada hubungan antara status gizi dengan DMF-T pada murid SD Negeri 1 Piton tahun 2020.

Keadaan responden berstatus gizi gemuk dengan DMF-T tinggi dapat terjadi karena dimungkinkan individu mengonsumsi makanan kariogenik (makanan manis) dengan frekuensi tinggi sehingga meningkatkan skor BMI (Body Mass Index) yang diimbangi dengan perilaku individu yang tidak peduli dan mengabaikan kesehatan mulutnya sehingga sisa makanan kariogenik (makanan manis) menetap lama di dalam mulut yang menguntungkan bagi bakteri untuk memetabolisme gula menjadi asam dan menurunkan $\mathrm{pH}$ rongga mulut sehingga terjadi penurunan $\mathrm{pH}$ rongga mulut secara terus menerus kemudian terjadilah demineralisasi gigi sehingga meningkatkan skor karies [14].

Keadaan responden berstatus gizi kurus dengan DMF-T tinggi dapat terjadi karena dimungkinkan individu memiliki frekuensi makan (terutama protein) yang rendah sehingga menurunkan skor BMI (Body Mass Index). Penelitian [14] menjelaskan bahwa keadaan responden berstatus gizi kurus dengan DMF-T tinggi memiliki kelenjar saliva yang mengalami atrofi sehingga menyebabkan aliran saliva menurun dan mengurangi buffer saliva yang akhirnya dapat meningkatkan terjadinya karies. Saliva tidak hanya mengandung antibodi berupa immunoglobulin $A$ sekretori (slgA) yang berperan dalam melindungi gigi geligi, juga terdapat komponen-komponen alamiah non spesifik seperti protein kaya prolin, laktoferin, laktoperoksidase, lisozim, serta faktor-faktor agregasi dan aglutinasi bakteri yang juga memiliki peran dalam melindungi gigi dari karies. Jadi, apabila asupan nutrisi seseorang itu berkurang, maka akan mengganggu sistem pertahanan gigi dan terjadilah karies.

Dalam penelitian [15] di India mengatakan bahwa tidak ada hubungan antara status gizi dengan karies. Konsep dari karies gigi yang mulanya berdasarkan konsep yang dikemukakan pada tahun 1962 yakni host, diet, microorganism telah berubah. Konsep modern dari karies gigi yakni termasuk faktor social dan perilaku. Sedangkan kegemukan pada anak dipengaruhi oleh diet, genetic, faktor perilaku dan psikologis, penyakit infeksi dan pemeliharaan kesehatan anak.

Sedangkan penelitian yang dilakukan oleh [16] di Turki juga mengatakan bahwa tidak ada hubungan yang bermakna antara status gizi dengan karies. Meskipun dalam studi pendahuluan mengindikasikan bahwa kemungkinan terdapat hubungan bermakna antara status gizi dengan karies namun pada hasilnya tidak terlihat adanya hubungan tersebut. Perlu adanya penelitian lanjutan mengenai gabungan antara evaluasi diet, komplikasi oralhygiene, status sosial ekonomi, faktor lainnya yang dimungkinkan sebagai pencetus.

Hasil analisis bivariat pada penelitian ini menunjukkan bahwa tidak ada hubungan antara status gizi dengan DMF-T pada murid SD Negeri 1 Piton $(p=0,261)$. Hasil penelitian ini bertentangan dengan hasil penelitian [2] [17]. Namun, penelitian ini sejenis dengan penelitian yang dilakukan oleh [15] [16][18] [19] dimana hasil yang diperoleh tidak ditemukan hubungan antara status gizi dengan karies gigi pada anak. 


\section{KESIMPULAN}

Berdasarkan hasil penelitian tentang "Hubungan Status Gizi Dengan DMF-T Pada Murid Di SD Negeri 1 Piton" maka disimpulkan bahwa persentase status gizi tertinggi yakni murid dengan status gizi kurus sedangkan persentase DMF-T tertinggi yakni murid dengan DMF-T tinggi serta tidak ada hubungan yang bermakna antara status gizi dengan DMF-T pada penelitian ini.

\section{UCAPAN TERIMAKASIH}

Kepada Ketua Jurusan Keperawatan Gigi Poltekkes Kemenkes Surabaya yang telah memberikan kesempatan untuk melakukan penelitian, serta dosen pembimbing yang telah senantiasa membimbing peneliti dan tak lupa Kepala Sekolah SD Negeri 1 Piton yang telah berkenan dan mengizinkan peneliti untuk melaksanakan penelitian.

\section{DAFTAR PUSTAKA}

[1] K. RI, "Infodatin Pusat Data Dan Informasi Kementerian Kesehatan RI."

[2] H. Y. Kartikasari and Nuryanto, "Journal of Nutrition College, Volume 3 , Nomor 3 , Tahun 2014 , Halaman 414-421 Journal of Nutrition College , Volume 3 , Nomor 3 , Tahun 2014 Online di : http://ejournal-s1.undip.ac.id/index.php/jnc Journal of Nutrition College , Volume 3 , Nomor 3 , Ta," vol. 3, pp. 414-421, 2014.

[3] Dinkes, "Hasil Utama Riset Kesehatan Dasar Jawa Timur 2018," Jakarta Badan Penelit. dan Pengemb. Kesehatan, Kementrian Kesehat. Republik Indones., pp. 1-82, 2018.

[4] A. A. D. Riani, Z. Meilawaty, and H. Hadnyanawati, "Digital Repository Universitas Jember Digital Repository Universitas Jember," pp. 193-201, 2013.

[5] S. Annisa, Zulmansyah, and D. Koesmayadi, "Hubungan Pola Menyikat Gigi terhadap Kejadian Karies Gigi pada Anak Usia 7- 10 Tahun di SDN Suryalaya Bandung Tahun Ajaran 2014-2015," pp. 97-104, 2015.

[6] P. J. Timur, RISET KESEHATAN DASAR PROVINSI JAWA TIMUR. 2013.

[7] M. Septikasari, Maestika septikasari, s.st., mph. .

[8] S. Hardiansyah, F. I. Keolahragaan, and U. N. Padang, "Majalah ilmiah," vol. 25, no. 2, pp. 207-217, 2003.

[9] R. Handayani, "FAKTOR-FAKTOR YANG BERHUBUNGAN DENGAN," vol. 2, no. 120, pp. 217-224, 2017.

[10] D. Pertiwi, D. Kusudaryati, and Y. A. Oktavia, "Status Gizi Berdasarkan Indeks Antropometritb / U Dan Imt / U Pada Anak Di SD Negeri Banyuanyar II Surakarta," pp. 449-456, 2018.

[11] Yulistianingrum and E. Rujianto, "University Research Colloquium 2016 ISSN 2407-9189 HUBUNGAN KONSUMSI JENIS MAKANAN KARIOGENIK DENGAN KEJADIAN KARIES GIGI PADA ANAK DI SDN KRANDON KUDUS,” pp. 132136, 2016.

[12] E. Mangkey, J. Posangi, and M. A. Leman, "GAMBARAN STATUS KARIES PADA SISWA SMP NEGERI I TOMOHON," vol. 3, 2015.

[13] Alini, "FAKTOR-FAKTOR YANG BERHUBUNGAN DENGAN KEJADIAN," vol. 2, no. 23, pp. 19-27, 2018.

[14] Hidayatullah, A. Rosihan, and Triawanti, "HUBUNGAN TINGKAT KEPARAHAN KARIES DENGAN STATUS GIZI KURANG DAN GIZI BAIK,” vol. I, no. 1, 2016.

[15] S. Tripathi and K. K. Kamala, "Relationship between obesity and dental caries in 
children - A preliminary study Abstract : Introduction :," vol. 2, no. 4, pp. 65-72, 2010.

[16] K. Cantekin, T. Gurbuz, S. Demirbuga, and T. Demirci, "Dental caries and body mass index in a sample of 12-year-old eastern Turkish children," pp. 77-80, 2012, doi: 10.1016/j.jds.2012.01.011.

[17] E. Aluckal, "Association between Body Mass Index and Dental Caries among Anganwadi Children of Belgaum City , India," pp. 844-848, 1941.

[18] D. Chen, Q. Zhi, Y. Zhou, Y. Tao, L. Wu, and H. Lin, "Association between Dental Caries and BMI in Children: A Systematic Review and Meta-Analysis.," Caries Res., vol. 52, no. 3, pp. 230-245, 2018, doi: 10.1159/000484988.

[19] K. Swaminathan, V. Anandan, S. Haridoss, and E. Thomas, "Correlation Between Body Mass Index and Dental Caries Among Three- to 12-Year-Old Schoolchildren in India : A Cross-Sectional Study," vol. 11, no. 8, 2019, doi:

10.7759/cureus.5421. 